\title{
A laboratory study to disentangle hydrological, mechanical and structural mechanisms of soil stabilisation by plant mucilage between eroding and depositional zones of a slope
}

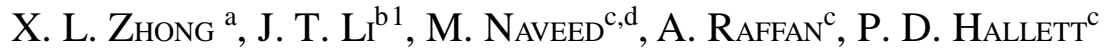

${ }^{\mathrm{a}}$ College of Natural Resources and Environment, South China Agricultural University,

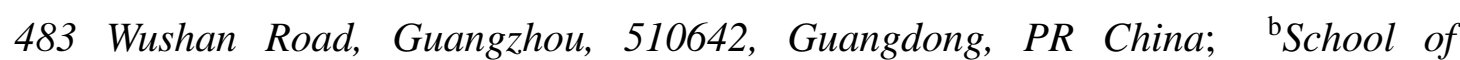
Geographical Sciences, Guangzhou University, 230 Waihuan West Road, Guangzhou, 510006, Guangdong, PR China; 'Institute of Biological and Environmental Sciences, University of Aberdeen, Cruickshank Building, St Machar Drive, Aberdeen, AB24 3UU, UK, and ${ }^{\mathrm{d}}$ School of Computing and Engineering, University of West London, St Mary's Road, Ealing, London, W5 5RF, UK

Running title: Soil stabilisation by mucilage and slope position

\footnotetext{
${ }^{1}$ Corresponding author. Tel: +86 15918779050

E-mail address: ljtgzhu@163.com (J. T. Li)
}

This article has been accepted for publication and undergone full peer review but has not been through the copyediting, typesetting, pagination and proofreading process which may lead to differences between this version and the Version of Record. Please cite this article as doi: $10.1111 /$ ejss.12955 


\section{Summary}

Biological exudates, such as plant mucilage, can greatly stabilise soils but as the mechanical and hydrological drivers depend much on soil particle size composition, eroding and depositional areas of a slope may respond differently. Soils from an eroded midslope and a depositional footslope in an arable farm were amended with chia (Salvia hispanica) seed mucilage at concentrations of $0 \mathrm{~g} \mathrm{C} \mathrm{kg}^{-1}, 0.46 \mathrm{~g} \mathrm{C} \mathrm{kg}^{-1}$ and $2.3 \mathrm{~g} \mathrm{C} \mathrm{kg}^{-}$ ${ }^{1}$ mucilage, formed into cores, and then imparted with wetting and drying (WD) cycles. Mucilage increased the stability of these inherently stable soils from $80 \%$ to $>98 \%$ water stable macroaggregates at OWD cycles regardless of slope position. Aggregate stability was maintained after 5WD cycles by mucilage, whereas the stability of unamended soil dropped by $66.7 \%$ in the footslope and $30.1 \%$ in the midslope compared with $0 \mathrm{WD}$. Underlying physical stability properties were measured by tensile strength and penetration resistance for mechanical, water sorptivity and repellency for hydrological, and micro-, meso-, macro- and total porosity for structural properties. Almost every soil physical property measured changed less with WD cycles if mucilage was present. Compared to unamended soil, $2.3 \mathrm{~g} \mathrm{C} \mathrm{kg}^{-1}$ mucilage amendment decreased water sorptivity from $0.289 \mathrm{~mm} \mathrm{~s}^{-1 / 2}$ to $0.122 \mathrm{~mm} \mathrm{~s}^{-1 / 2}$ in the midslope and $0.230 \mathrm{~mm} \mathrm{~s}^{-1 / 2}$ to $0.182 \mathrm{~mm} \mathrm{~s}^{-1 / 2}$ in the footslope after 5 WD cycles. Aggregate stability, total porosity and water sorptivity were correlated. In the midslope, hydrology and penetration resistance were affected most, likely driven by mucilage deposition in the macropores of this more coarsely textured soil. In the footslope, the greater impact of mucilage on tensile strength was likely driven by buffering of 
macroporosity formation by WD cycles in this finer textured soil.

Keywords: hydrological, mechanical, plant mucilage, soil stability, slope, structural

\section{Highlights:}

- We explored how slope position interacts with plant mucilage to drive soil physical stability.

- Changes in soil physical stability by plant mucilage have rarely been considered with slope position.

- Interactions between mucilage and soil particles caused greater physical stability in midslope than footslope.

- Mucilage stabilised soil by easing changes in pore structure, DOC redistribution and water repellency, with particle bonding less important. 


\section{Introduction}

Soil erosion is a worldwide issue of both social and environmental concern. Plant exudates and mucilages could be very important to the stabilisation of soil against erosion (Wang et al., 2017) as they have adhesive properties that bind soil particles through polymer bridges, they retain water providing physiological advantage to plant stress tolerance (Brax et al., 2017), and they can also enhance soil hydrological stability by reducing the rapid wetting rate of dry soils (Zhang et al. 2004; Peng et al., 2011). Plant exudates and mucilages interacting together with intense wetting and drying (WD) cycles due to evapotranspiration, stimulate changes in the formation and stability of soil structure (Morel et al., 1991). On an eroding slope, the action of plant roots aggregating soil through a combination of particle bonding by plant exudates and mucilages, and physical enmeshment are major soil stabilisation mechanisms (Engelbrecht et al., 2014; Deng et al., 2012). Although it well known that vegetation restoration could greatly stabilize soil against erosion, the role or contribution of plant exudates and mucilages on soil physical stabilisation has received little attention (Traoré et al., 2000). However, the effect of plant exudates and mucilages on soil stabilisation against water erosion may vary at different slope positions.

On a slope, selective transport induced by water erosion drives soil particles, soil carbon and soil microaggregates to be redistributed downslope (Papiernik, et al., 2005; Shi, et al., 2013; Chartier et al., 2013). Therefore, in an eroded area more coarse soil particles (e.g. sands and gravels) and less carbon may remain in situ, restricting soil aggregation (Huang, et al., 2014). This change in soil particle size composition along 
the slope may cause great differences in pore size distribution between the midslope and the footslope. The greater proportion of fine material in footslope soils results in more micropores, which could preferentially absorb plant exudates, leading to enhanced aggregation (Benard et al., 2018; Morel et al., 1991). Coarser particle sizes in the midslope lead to macropores where organic substances with high molecular weight may be preferentially deposited through capillary action (Zhang et al., 2008), potentially forming a gel film coating on macropore walls or bridges that block pore throats (Carminati et al., 2016). Therefore, the difference in soil particle size distribution between midslope and footslope could cause a great discrepancy of binding capacity, interparticle cohesion and soil aggregate formation. However, the changes in soil physical stabilisation processes by the action of plant exudates have rarely been considered in relation to slope position.

Soil physical stability can be divided into soil mechanical and hydrological stability. Le Bissonais (1996) pointed out the main breakdown mechanisms of soil aggregates are slaking, breakdown by differential swelling, and mechanical breakdown by raindrop impact. The hydrological stability of soil aggregates depends on pore structure controlling the release of entrapped air (Le Bissonais, 1996) and the proportion of hydrophobic organic compounds that alter soil wetting properties (Hallett et al., 2001). WD cycles have been indicated to be one of the non-biological factors driving soil water repellency development. Repeated WD cycles may redistribute soil hydrophobic dissolved organic compounds to the drying surfaces of aggregates (Zhang et al., 2004), or depositing mucilage in smaller cavities among the particle surfaces during drying 
(Benard et al., 2018). These processes may create a hydrophobic surface that reduces the soil aggregate wetting rate, thereby enhancing slaking resistance.

Mechanical stabilisation is caused by interparticle bonding and the soil pore structure (Le Bissonais, 1996). It can be quantified from tensile strength or penetration resistance (Peng et al., 2011). Tensile strength is the stress required to break a soil aggregate, and has been found to be a sensitive indicator of soil structural condition (Dexter \& Watts, 2001). Soil penetration resistance is important for plant growth and soil biological activity (Bengough et al., 1991; Sinnett et al., 2008). Mechanical stabilisation of soil aggregates is governed by the properties of soil particle size composition, moisture and organic substances. Both slope position and plant mucilage should affect all these properties, driving different dominant stabilisation mechanisms of soil aggregates along an eroding slope.

We hypothesise that soil in the eroded midslope will be stabilised more by plant mucilages than the depositional footslope due to soil particle size composition. These differences will be exacerbated under WD cycles due to a greater redistribution of mucilage to aggregate/macropore surfaces in midslope soil compared to footslope soil. Dissolved organic carbon (DOC) and a range of processes underpinning soil structural stability were measured: macroaggregate water stability against fast wetting, sorptivity, water repellency (WR), tensile strength (TS), penetration resistance (PR), and porosity. The objectives of this study were: (i) to understand the interaction between plant mucilage and soil particles on soil pore structure evolution and DOC redistribution; and (ii) to explore the mechanisms of soil mechanical and hydrological and structural 
stability by plant mucilage amendment and slope position.

\section{Materials and methods}

\section{Soil sampling}

Soils were sampled from $0-15 \mathrm{~cm}$ depth at the midslope and footslope of a commercial arable farm near Montrose in the northeast of the United Kingdom ( $56^{\circ} 41^{\prime}$ $\left.1.0494 " \mathrm{~N}, 2^{\circ} 36^{\prime} 0.126^{\prime \prime} \mathrm{W}\right)$. The slope was north-facing, with about a $5^{\circ}$ gradient, 1500 m distance and 20.83 m elevation difference between sampling locations. At the time of sampling, the field was under potatoes, with winter wheat planted the previous year, and other years with barley or oil-seed rape under a variable rotation. The soil at the midslope is classified as a Dystric Cambisol and at the footslope it is a Gleyic Cambisol. It formed from reddish brown till composed of andesitic lava, sandstone and conglomerate (Glenworth et al., 2016). The area has a temperate maritime climate

with an annual rainfall of approximately $683 \mathrm{~mm}$. At the midslope and footslope, a mixed bulked soil sample was collected from 5 random spots in the area within a diameter of $10 \mathrm{~m}$. Each bulked soil sample was then air-dried and passed through a 2 mm sieve with leaves and plant roots removed with tweezers, and then the soil was mixed by hand with a trowel to improve homogeneity.

Some chemical and physical characteristics of the soils are shown in Table 1. Sand content in the midslope was significantly greater than in the footslope $(p<0.01)$, with a 3 times difference if only sand particles larger than $0.2 \mathrm{~mm}$ were considered. However, the silt and clay contents in the midslope were significantly less than in the footslope 
$(p<0.01)$. The depletion of finer particles from the midslope and increase at the footslope suggests erosion.

Table 1 Selected soil properties in top soil layer from the midslope and footslope of the slope

\section{Plant mucilage extraction and soil cores preparation}

Mucilage was extracted from the seed coating of chia seeds. It has a chemical composition (primarily glucose, xylose and uronic acids) (Lin et al., 1994) and physical properties similar to rhizodeposits produced by lupin and maize roots (Carminati, 2013). Mucilage was extracted by hydrating $50 \mathrm{~g}$ of dry chia seeds in $500 \mathrm{ml}$ deionized water, followed by 2 minutes mixing with a magnetic stirrer and 2 hours resting at room temperature $\left(20^{\circ} \mathrm{C}\right)$. Seeds were separated from their hydrated mucilage coating by squeezing the mixture by hand through a nylon mesh $(0.5 \mathrm{~mm})$. The separated mucilage was stored in an airtight glass jar at $4{ }^{\circ} \mathrm{C}$ before amending into soil. The solid concentration of the collected mucilage was $9.2 \pm 0.3 \mathrm{~g} \mathrm{~kg}^{-1}$. The dry mass of sieved mucilage consisted of $407.8 \pm 1.4 \mathrm{~g} \mathrm{~kg}^{-1}$ total organic carbon, $10.9 \pm 0.1 \mathrm{~g} \mathrm{~kg}^{-1}$, total nitrogen (TN) and $1.55 \pm 0.02 \mathrm{~g} \mathrm{~kg}^{-1}$ DOC.

Soil was wetted to about $0.25 \mathrm{~g} \mathrm{~g}^{-1}$ water content, which provided a consistency that allowed for packing into soil cores and was slightly drier than field capacity. This was achieved by wetting, $100 \mathrm{~g}$ sieved, air-dry soil with $25 \mathrm{~g}$ of either the original extracted mucilage, a 5 times dilution of the original extracted mucilage or deionized water. Mixing was done by hand with a spatula, with the solution applied gradually by dripping across the surface and constantly mixing. Agglomeration during mixing 
occurred, which was broken up to improve homogeneity. This mucilage amendment was equivalent to an amendment of $2.3 \mathrm{~g} \mathrm{C} \mathrm{kg}^{-1}$ soil for the undiluted mucilage treatment and $0.46 \mathrm{~g} \mathrm{C} \mathrm{kg}^{-1}$ soil for the 5 times dilution treatment. From herein we refer to the mucilage amendment treatments by this amount of $\mathrm{C}$ added to the soil.

The mixed soils were equilibrated for 24 hours at $4{ }^{\circ} \mathrm{C}$ and then packed into PVC cores $(\mathrm{H}=1.5 \mathrm{~cm}, \mathrm{D}=3 \mathrm{~cm})$ to $1.55 \mathrm{~g} \mathrm{~cm}^{-3}$ bulk density, which was similar to field conditions. Quantitative filter paper was secured to the bottom of the PVC cylinder with a rubber band. For each treatment, 39 soil cores were prepared, producing a total of 234 soil cores for the 2 soils and 3 mucilage treatments. The soil cores were stored in sealed plastic bags for 24 hours at $4{ }^{\circ} \mathrm{C}$ for further equilibration.

\section{Wetting and drying cycles}

The packed cores were treated with either 0, 1 or 5 WD cycles. Each WD cycle lasted $48 \mathrm{~h}$, consisting of wetting at $0 \mathrm{kPa}$ water potential with deionized water for $6 \mathrm{~h}$ at $4{ }^{\circ} \mathrm{C}$ followed by drying in an oven for $42 \mathrm{~h}$ at $40{ }^{\circ} \mathrm{C}$. Through wetting of the base of the core by capillary action and drying from the top surface by heat, a ‘top’ surface was produced to explore whether DOC illuviation from the soil and added plant mucilage exacerbated observed physical impacts. WD cycles mimic processes that may occur towards the surface of soil or macropores that define interaggregate boundaries.

\section{Soil physical characteristics}

Soil aggregate stability was measured by the fast wetting method. Briefly, $10 \mathrm{~g}$ air-dried soil aggregates were immersed in $100 \mathrm{~cm}^{3}$ of deionized water for $10 \mathrm{~min}$. The 
slaked soils were then transferred to a $0.25 \mathrm{~mm}$ sieve that was moved up and down 20 times for 1 minute to a depth of $1 \mathrm{~cm}$ under the water. Soil remaining on the sieve was dried at $40 \square$ for $24 \mathrm{~h}$ and then weighed. The aggregate stability index was expressed by the weight percent of $>0.25 \mathrm{~mm}$ water stable aggregates. There were 3 replicates.

Soil pore size distribution and penetration resistance (PR) were measured on another 5 replicates on samples equilibrated to $-5 \mathrm{kPa}$ and then $-30 \mathrm{kPa}$ water potential. Cores were first saturated for $12 \mathrm{~h}$ and then equilibrated for 3 days for each water potential using a tension table (EcoTech, Bonn, Germany). PR was measured with a needle penetrometer ( $30^{\circ}$ cone opening angle and $1.87 \mathrm{~mm}^{2}$ base area) fitted to a loading frame (Zwick Z05, Germany) with a $5 \mathrm{kN}$ load cell (accurate to $0.01 \mathrm{~N}$ ). The crosshead speed was set to $2 \mathrm{~mm} \mathrm{~min}^{-1}$. The maximum force $\left(F_{\max }, N\right)$ was recorded from the surface to $6 \mathrm{~mm}$ depth of a core and used to calculate PR by dividing by the base area (Bengough et al., 1997). The weight and volume of each soil core was measured after saturating, drying at $-5 \mathrm{kPa}$ and $-30 \mathrm{kPa}$, and after drying at $105^{\circ} \mathrm{C}$. Macroporosity, mesoporosity and microporosity were inferred from the water content at each water potential, corresponding to pore diameter cut-offs of $60 \mu \mathrm{m}$ at $-5 \mathrm{kPa}$ and $10 \mu \mathrm{m}$ at $-30 \mathrm{kPa}(\mathrm{Kay}, 1990)$.

On a further 5 replicates that had been dried at $40 \square$, tensile strength (TS) was measured by the indirect tension test using the same Zwick loading frame and load cell used for PR measurements. The soil disc was removed from its plastic ring and placed vertically with opposite poles between two flat platens that compressed together during testing. The crosshead speed was set to $6 \mathrm{~mm} \mathrm{~min}^{-1}$, and the applied force was recorded 
every $0.1 \mathrm{~s}$. TS in $\mathrm{kPa}$ was calculated as

$$
T S=1000 \times\left(\frac{2 F_{\max }}{\pi D L}\right)
$$

where $F_{\max }(\mathrm{N})$ is the applied load at failure, $D(\mathrm{~mm})$ is the diameter of soil core and $L(\mathrm{~mm})$ is the length of the soil core (Czarnes et al., 2000).

Bulk density was measured with the same core used for TS, taking shrinkage during drying into account by measuring the height and diameter with calipers.

Sorptivity and water repellency were measured on the top and bottom surfaces of the soil core, using the approach developed by Hallett \& Young (1999). After measuring TS, the soil sample was split in half, with each half used to measure either water sorptivity $\left(\mathrm{S}_{\mathrm{w}}\right)$ or ethanol sorptivity $\left(\mathrm{S}_{\mathrm{E}}\right)$. The soil cores were dried again at $40{ }^{\circ} \mathrm{C}$ for $12 \mathrm{~h}$ before testing. A $2 \mathrm{~mm}$ diameter infiltrometer tip, which was connected to a liquid reservoir on a logging balance (accurate to $0.1 \mathrm{mg}$ ), was brought into contact with the soil. The tip was covered with nylon mesh ( $4 \mu \mathrm{m}$ in pore diameter) to allow for rapid liquid flow and the development of a hydraulic head of $-10 \mathrm{~mm}$ to reduce macropore flow. Sorptivity was calculated based on the equations presented in Hallett \& Young (1999), and used to determine the water repellency index (WR) from the ratio between $S_{E}$ and $S_{W}$, multiplied by 1.95 to account for surface tension and viscosity differences between the liquids.

\section{Soil chemical characteristics}

After measuring $S_{W}$, the same soil was used to measure soil DOC. Soils were first dried again for 12 hours at $40{ }^{\circ} \mathrm{C}$ and then divided into top (0-2 mm depth from the top surface), interior (2-13 $\mathrm{mm}$ from the top surface) and bottom (13-15 $\mathrm{mm}$ from the top 
surface) layers for samples exposed to 0 and 5 WD cycles. Soil samples were weighed, ground and passed through a $2 \mathrm{~mm}$ sieve. DOC was extracted using the method of Ghani et al. (2003), and determined immediately by a Lab-TOC analyser (Pollution and Process Monitoring Ltd, Kent, UK). Briefly, DOC was extracted by adding $30 \mathrm{ml}$ deionized water with a 1:10 (w/w) soil-to-water ratio into $3 \mathrm{~g}$ of soil sample. The suspension was stirred on a horizontal shaker at $120 \mathrm{rpm}$ for an hour at room temperature. Next, a separation was done by centrifugation at $3500 \mathrm{rpm}$ for $20 \mathrm{~min}$. The supernatant was filtered to $<0.45 \mu \mathrm{m}$ through a microfiltration membrane to obtain a solution for DOC determination.

The average DOC (DOC ave) concentration of the whole soil core was calculated from the DOC concentrations by

$$
D O C_{\text {ave }}=\frac{D O C_{t} \times W_{t}+D O C_{i} \times W_{i}+D O C_{b} \times W_{b}}{W_{t}+W_{i}+W_{b}}
$$

where the subscripts $t, i$ and $b$ refer to top, interior and bottom layers, respectively, and $W$ is weight.

Soil pH and EC were measured with a pH meter (Hannah Instruments, UK) in 1:2.5 (w/w) and 1:5 soil-to-water suspensions, respectively. Soil texture was measured using the hydrometer method (Gee \& Bauder, 1986). Soil organic carbon (SOC) and TN were measured by Carlo Erba Instruments, NA 2500 Elemental Micro Analysis, before detection, soil was treated with $0.1 \mathrm{M} \mathrm{HCl}$ for removing inorganic C.

\section{Statistical analyses}

Three-way analysis of variances (ANOVA) were used to test the effects of plant mucilage amendment, WD cycles, and slope position on aggregate stability, PR, TS, $\mathrm{S}_{W}$ 
and $\mathrm{S}_{\mathrm{E}}, \mathrm{WR}$, DOC concentrations, and porosity. Significant difference between means were evaluated by Fisher's least significant difference (LSD) at the 95\% confidence level, and the LSD values were calculated following Webster (2007). Pearson correlation analysis was used to examine the relationships among soil parameters. All statistical analyses were carried out in SPSS version 19.0, and significance for all statistical analysis was accepted at $\mathrm{p}<0.05$. Graphs and linear regressions were made by Origin 8.5 .

\section{Results}

\section{DOC redistribution in soil core}

In unamended soil samples, 5 WD cycles increased DOC by $46.5 \%$ in the midslope and $37.7 \%$ in the footslope, compared to 0 WD cycle (Fig. 1). DOC concentrations in different parts of the soil cores were affected significantly by mucilage amendment and WD cycles $(p<0.001)$ (Fig. 1, Table_1_Suppinfo). The top layers of the soil core had appreciably more DOC ( $p<0.001$ ), containing 21.0\%- 29.0\% of the whole soil core DOC at 0 WD cycle, and $39.1 \%-56.8 \%$ of the whole soil core DOC after 5 WD cycles. However, the weight of DOC in the top layer was only $13.3 \%$ of the total DOC in the soil core. In the top layer, the midslope had greater DOC than the footslope $(p<0.001)$, but DOC concentration in the interior and bottom layers did not vary between the midslope and footslope $(p>0.05)$. DOC concentrations in the 2.3 $\mathrm{g} \mathrm{C} \mathrm{kg}^{-1}$ added mucilage treatments were much greater than the water and $0.46 \mathrm{~g} \mathrm{C} \mathrm{kg}^{-}$ ${ }^{1}$ added mucilage treatments $(p<0.001)$. Again, the top layer had the greatest DOC, with 
$2.3 \mathrm{~g} \mathrm{C} \mathrm{kg}^{-1}$ added mucilage having $89.4 \%$ greater DOC in the midslope and $58.2 \%$ greater DOC in the footslope compared to unamended soil.

For the whole soil cores, DOC redistributed with mucilage amendment and WD cycles. Adding $2.3 \mathrm{~g} \mathrm{C} \mathrm{kg}^{-1}$ mucilage resulted in more DOC movement to the top of the core surface than water or $0.46 \mathrm{~g} \mathrm{C} \mathrm{kg}^{-1}$ added mucilage. This was exacerbated by 5 WD cycles. However, different parts of soil cores presented different changes. For both slope positions, frequent WD cycles resulted in about $80 \%-100 \%$ DOC being in the top layers, with only small changes of DOC measured in the interior and bottom layers (Table 2).

Table 2. The mass balance of dissolved organic carbon (mg) in different depths of soil cores (kg) with mucilage amendment and wetting and drying cycles.

\section{Soil aggregate stability}

Before imposing WD cycles, both the midslope and footslope soils were inherently stable and similar, with greater than $80 \%$ water stable aggregates $>0.25 \mathrm{~mm}$ size (Fig. 2). Mucilage caused a significant increase in aggregate stability at 0 WD cycle $(p<0.001)$. After 5 WD cycles, aggregate stability dropped by $11.1 \%-66.7 \%$ in the footslope and $4.3 \%-30.1 \%$ in the midslope, but this was countered by mucilage. For $2.3 \mathrm{~g} \mathrm{C} \mathrm{kg}^{-1}$ added mucilage treatment, aggregate stability was maintained close to 0 WD level and it was much greater than for unamended soils $(p<0.001)$. The impacts were greater for footslope soil $(p<0.001)$.

\section{Tensile strength (TS)}

Soil TS was affected most by slope position and WD cycles and to a lesser extent 
by plant mucilage amendment $(p<0.001)$ (Fig. 3, Table_1_Suppinfo). TS in footslope soil was $36.1 \% \sim 134.5 \%$ greater than in the midslope between the same WD cycles ( $p$ $<0.001)$. TS had a large drop with WD cycles, decreasing by 50.5\%-75.3\% in midslope soil and 47.8\%-75.3\% in footslope soil between 0 and 5 WD cycles $(p<0.001)$ (Fig. 3). This decrease was attenuated by $2.3 \mathrm{~g} \mathrm{C} \mathrm{kg}^{-1}$ added mucilage, resulting in TS increases of $87.7 \%$ in midslope and $77.4 \%$ in footslope soils compared to unamended soil $(p<0.001)$. At 0 and 1 WD cycles, however, plant mucilage caused gradual TS reductions in the footslope soil, but not in the midslope soil. Soil TS had significant positive correlation with the percentage of water stable macroaggregates for both slope positions ( $p<0.001$ ), reaching coefficients up to 0.8 (Fig. 7).

\section{Soil porosity and pore size distribution}

Footslope and midslope soils were packed to the same initial porosity ( $p>0.05)$, but frequent WD cycles increased soil porosity (Fig. 4) $(p<0.001)$. This porosity increase was in macroporosity and mesoposity, at the expense of microporosity which decreased with WD cycles. For unamended soil at 0 WD cycles, there was $26.5 \%$ greater macroporosity in midslope soil compared to footslope soil, but $12.6 \%$ less mesoporosity and 7.2\% less microporoisity (Fig.4). Macropore differences between the midslope and footslope soils reflect the textural differences between the slope locations.

The porosity changes with WD cycles, however, were attenuated by $2.3 \mathrm{~g} \mathrm{C} \mathrm{kg}^{-1}$ added mucilage where changes were minimal $(p<0.05)$, and far less than soils amended with water or $0.46 \mathrm{~g} \mathrm{C} \mathrm{kg}^{-1}$ mucilage. After $5 \mathrm{WD}$ cycles, soils with $2.3 \mathrm{~g} \mathrm{C} \mathrm{kg}^{-1}$ added mucilage formed $8.5 \%$ and $50.1 \%$ less macropores and mesopores, respectively, in the 
midslope, and $24.0 \%$ and $43.6 \%$ less macropores and mesopores, respectively, in the footslope compared to unamended soils $(p<0.05)$. Moreover, $2.3 \mathrm{~g} \mathrm{C} \mathrm{kg}^{-1}$ added mucilage had a small impact on micropore increases after 5 WD cycles compared to unamended soils, with the effect much greater for the footslope soil.

\section{Penetration resistance (PR)}

Midslope soils that were not amended with mucilage had greater PR than footslope soil, by $34.2 \%$ at $-5 \mathrm{kPa}$ water potential and $72.0 \%$ at $-30 \mathrm{kPa}$ water potential $(p<0.001)$ (Table 3). The F value indicates that slope position was the major factor affecting PR, with mucilage having the next greatest impact (Table_1_Suppinfo). Adding 2.3 g C kg${ }^{1}$ mucilage significantly increased soil PR in both midslope and footslope $(p<0.001)$. However, WD cycles showed a different trend between PR at $-5 \mathrm{kPa}$ and $-30 \mathrm{kPa}$, with a $19.1 \%$ decrease at $-5 \mathrm{kPa}$ and a $6.2 \%$ increase at $-30 \mathrm{kPa}$ after $5 \mathrm{WD}$ cycles compared to 0 WD cycles. Adding $2.3 \mathrm{~g} \mathrm{C} \mathrm{kg}^{-1}$ mucilage had a greater impact on PR after $5 \mathrm{WD}$ cycles for midslope than footslope soils (Table 3). Compared to unamended soils, PR values in $2.3 \mathrm{~g} \mathrm{C} \mathrm{kg}^{-1}$ added mucilage were greater by $55.0 \%$ in the midslope and $38.9 \%$ in the footslope at $-5 \mathrm{kPa}$ water potential, and $22.6 \%$ in the midslope and $8.4 \%$ in the footslope at -30 kPa water potential.

Table 3. Soil penetration resistance as affected by slope position, mucilage amendment and wetting and drying (WD) cycles at different water potentials

Water sorptivity $\left(S_{W}\right)$, ethanol sorptivity $\left(S_{E}\right)$ and water repellency (WR)

These soils had small WR levels that were affected most by mucilage amendment 
on the drying surface at the top of the core, and by slope position at the bottom of the core (Tables 4, Table 1- Suppinfo)). With WD cycles, WR generally increased at the top surface $(p<0.001)$, with the impact exacerbated by increasing mucilage concentration $(p<0.001)$. At the bottom of the core, however, WD cycles had no effect on the WR of the midslope soil ( $p>0.05)$ and caused a decrease in the footslope soil ( $p$ $<0.001)$.

The underpinning driver of soil stabilisation by WR is its impact on $S_{W}$. Whereas WD cycles increased $S_{W}$ by over $65 \%$ at the top surface for either midslope or footslope soil unamended with mucilage, when soils were amended with $2.3 \mathrm{~g} \mathrm{C} \mathrm{kg}^{-1}$ mucilage the $S_{W}$ dropped by $13.5 \%$ in the midslope soil and increased by $29.1 \%$ in the footslope soil. By 5 WD cycles, there was a large increase in $S_{E}$ for all treatments, but mucilage amendment decreased the amount of change.

Soil WR were significantly positively correlated with DOC concentration regardless of slope positions $(p<0.001)$. Their coefficients reached up to 0.82 and 0.79 for midslope and footslope, respectively (Fig.6).

Table 4. Sorptivity and Repellency of soil cores formed from soil as affected by slope position, mucilage amendment and wetting and drying (WD) cycles

\section{Discussion}

Plant mucilage had a positive impact on soil physical stability regardless of slope position (Fig. 2), but the dominance of different stabilisation mechanisms differed (Figs. 3-4, Tables 3-4). The most significant finding from this study was the attenuation of 
physical weathering stresses by plant mucilage, simulated by imposed WD cycles. Almost every soil physical property measured changed less with WD cycles if mucilage was present, with impacts greatest for the larger mucilage concentration. This generally agrees with previous studies (Morel et al., 1991; Traoré et al., 2000; Peng et al., 2011) that found plant mucilage increased soil physical stability by improving bond strength of soil particles, diminishing wetting rate, modifying soil porosity and reducing soil slaking stresses through increased water repellency. A schematic model of soil physical stability as affected by slope position, plant mucilage amendment and WD cycles is shown in Fig. 5.

\section{Impact of plant mucilage at different slope positions}

The new understanding from our study is to disentangle how slope position interacts with plant mucilage to drive soil physical stability. Compared to the midslope, the proportion of clay and silt in the footslope was greatly increased due to soil erosion, which redistributes soil particles, water and carbon in the landscape (Table 1) (Chartier et al., 2013; Shi et al., 2013). At the midslope, removal of finer material by colluviation (Table 1) would result in less interparticle bonding (Hallett et al., 1995), as reflected in its smaller tensile strength compared to the footslope soil (Fig. 3). When the soils were wet, the finer material in the footslope soils eased penetration resistance (Oleghe et al., 2017) compared to the midslope soils (Table 3). Mucilage amendment increased penetration resistance at either slope position, but by 5 WD cycles the increases were greater in midslope than footslope soils at either water potential. Hydrological behaviour was affected more in the midslope than the footslope, with water sorptivity 
driven by the combined effects of WD cycles, pore structure changes (as suggested by ethanol sorptivity) (Table 5) and water repellency (Table 4). These hydrological and mechanical processes interacted to affect soil aggregate stability, which was decreased far more with WD cycles in the footslope compared to the midslope, but was mitigated by mucilage at both slope positions.

Table 5. Correlations between soil hydrological and mechanical properties and soil pore structure

\section{Mechanical stabilisation by plant mucilage}

Plant mucilages are viscoelastic gels composed of large molecular weight organic compounds, low molecular weight organic acids and amino acids (Brax et al., 2017; Naveed et al., 2017). In soils, lower molecular weight organic substances add to DOC, which under WD cycles bind to soil particles and micropore surfaces through adsorption (Chenu \& Guerif, 1991; Henao \& Mazeau, 2009), surface tension and capillary forces of plant mucilage (Naveed et al., 2019). Larger molecular weight substances in plant mucilage are more viscous, so are more likely to occupy larger void spaces (macropore) between larger soil particles (sands and aggregates). When soils dry, macropores are drained first, so these larger size organic substances may form a gel film coating on macropore walls or bridges that block pore throats (Carminati et al., 2016). This has a mechanical effect by binding "loose” soil particles (Zhang et al., 2008; Peng et al., 2010), and a hydrological effect by clogging pores and inducing water repellency (Carminati et al., 2016; Zhang et al., 2004). 
Amending soils with chia mucilage was to simulate rhizosphere soil in cores large enough to measure soil physical properties, as described by other studies (Peng et al., 2011; Oleghe et al., 2017). It allowed for mechanisms driving soil stability (Le Bissonnais, 1996) to be disentangled, such as tensile strength to quantify bond energy between soil particles (Czarnes et al., 2000; Peng et al., 2011). In the study, $2.3 \mathrm{~g} \mathrm{C} \mathrm{kg}^{-}$ ${ }^{1}$ added mucilage to either midslope or footslope soils increased aggregate stability, especially when soil was exposed to multiple WD cycles $(p<0.05)$ (Fig. 2). Moreover, $2.3 \mathrm{~g} \mathrm{C} \mathrm{kg}^{-1}$ added mucilage caused the smallest drop in tensile strength (Fig. 3) and the smallest increase in macroporosity (Fig. 4) caused by WD cycles. Given that tensile strength decreased with increasing mucilage concentration in the footslope soil and was hardly changed in the midslope soil at 0 WD cycles, the mechanical stabilisation by mucilage observed at 5 WD cycles was more likely due to its impact on pore structure than bond energy. Significant correlations between tensile strength and different pore size classes were found (Table 5) $(p<0.01)$. The $0.46 \mathrm{~g} \mathrm{C} \mathrm{kg}^{-1}$ added mucilage treatment had similar pore structure to unamended soils across the WD treatments (Fig. 4), but weaker tensile strength at 0 and 1 WD cycles for midslope and footslope soil. This suggests the mucilage decreased bond energy, but to disentangle directly would need fracture mechanics tests with imposed pore structures (Zhang et al., 2008) or interparticle bond tests (Cole et al., 2012). High molecular weight compounds found in plant mucilage and other exopolysaccharides have been found to increase dry soil strength in most studies (Chenu \& Guerif, 1991; Cole et al., 2012; Peng et al., 2011), although Czarnes (2000) found dextran had no impact. The amount of clay along the 
slope influenced the trends we observed, likely driven by differences in bonding between exopolysaccharides to sand (Cole et al., 2012), silt and clay (Henao \& Mazeau, 2009).

For both the footslope and midslope soils, tensile strength correlated with aggregate stability (Fig. 7), but given the arguments about particle bonding presented above, the drivers may be due to pore structure stabilisation and hydrological processes, rather than interparticle bonding by the plant mucilage. During drying, mucilage entraps water (Buchmann \& Schaumann, 2017) and decreases the rate of water loss (Deng et al., 2015), and during wetting mucilage imparts hydrophobicity that decreases the rate of water infiltration (Ahmed et al., 2018). These hydrological drivers, coupled with enhanced microstructural stability (Brax et al., 2017), could attenuate WD cycle induced pore structure changes. Microstructural stabilisation was possibly operating at a micrometer scale, that would be too small for the tensile strength measurement (larger than centimeter scale) to capture (Hallett et al., 1995). As discussed earlier, penetration resistance, measured at -5 and $-30 \mathrm{kPa}$ water potential, suggest that mucilage increased microstructural stability of wet soil (Table 3).

\section{Hydrological stabilisation by plant mucilage}

Hydrological processes were quantified by water sorptivity, ethanol sorptivity and water repellency, which provide information about the rate of water infiltration and the disruptive effect of energy dissipation caused by rapid wetting (Czarnes et al., 2000). In this study, increases in water and ethanol sorptivity in both midslope and footslope soils with increasing WD cycles were attenuated by plant mucilage (Table 4). Ethanol 
sorptivity depends on pore structure, as illustrated by the correlation we found (Table 5). Water sorptivity changed less with WD cycles in mucilage amended soils due to the development of water repellency. This was likely driven by the movement of mucilage to the top of the core when the soil dried, with the greatest impact observed for soils with $2.3 \mathrm{~g} \mathrm{C} \mathrm{kg}^{-1}$ added mucilage. The impact on water repellency of $0.46 \mathrm{~g} \mathrm{C}$ $\mathrm{kg}^{-1}$ added mucilage was insignificant, possibly because the smaller volume of mucilage was deposited in contact regions between soil particles, forming thin filaments that were bypassed by infiltrating water (Benard et al., 2018). DOC was also mobilised by WD cycles (Fig. 1), which was correlated to increased water repellency (Fig. 6). On closer examination, however, DOC in unamended soils changed markedly between 0 and 5 WD cycles (Fig.1) but did not result in increased water repellency (Table 4). This agrees with Zhang et al. (2004) who found no correlation between the concentration of native DOC in soil and water repellency. Mucilage was driving the development of water repellency in our study.

It was expected that mucilage would affect the physical behaviour of midslope soil more than footslope soil because of its coarser texture driven by soil erosion. For aggregate stability the reverse was found, with footslope soils destabilised far more by WD cycles, but stabilised more by mucilage amendment after 5 WD cycles. Bond energy is generally assumed to be the greatest driver of soil stabilisation by mucilage, but our results suggest that mucilage buffering pore structure dynamics and inducing water repellency have greater impact. With simulated physical weathering by WD 
cycles, mucilage from plants has a large positive impact on stabilising soils on a slope, particularly in the footslope that has received unstable soil through colluviation.

Our experiment used idealised conditions of initially homogenised soils amended with a single mucilage input so that physical testing was possible. Using the same approach, exploring a broader range of soils and environmental stresses, particularly the impact of the severity of WD treatments, provides an opportunity for further study. There is scope to adopt new small-scale approaches to allow hydrological and mechanical processes driving soil stabilisation by roots and rhizodeposits to be measured along a slope in planted samples from controlled glasshouse experiments and in cores extracted from the field (Naveed et al., 2018).

\section{Conclusion}

This study has demonstrated that plant mucilage improved mechanical, hydrological and structural stabilisation mechanisms to a different extent depending on slope position. In the eroding midslope, more coarse particles, macroporosity and DOC accumulation on the surface of soil cores, may cause mucilage to impart stronger microstructural stabilisation and a greater drop soil wetting rate compared to footslope soil. This was reflected in the greater increase tensile strength, penetration resistance and water repellency for midslope compared to footslope soil after multiple WD cycles. However, there was less of an increase in soil macroaggregate stability caused by mucilage in the midslope because unstable aggregates were removed by erosion and deposited in the footslope. Soil hydrological and mechanical properties that drive soil 
stability in different slope positions were therefore mainly driven by the interaction of the plant mucilage with soil particles by attenuating changes in the soil pore structure, DOC redistribution and water repellency.

\section{Acknowledgments}

This work was financially supported by the National Natural Science Foundation of China (Project No. 41101278, 41101302), the State Scholarship Fund from China Scholarship Council (201408440300 and 201308440342) and the Biotechnology and

Biological Sciences Research Council (BBSRC) project 'Rhizosphere by Design' (BB/L026058/1).

\section{Data Availability Statement}

The data used to support the findings of this study are available from the corresponding author upon request. 


\section{References}

Ahmed, M.A., Zarebanadkouki, M., Ahmadi, K., Kroener, E., Kostka, S., Kaestner, A. \& Carminati, A., 2018. Engineering Rhizosphere Hydraulics: Pathways to Improve Plant Adaptation to Drought. Vadose Zone Journal. 17, DOI:10.2136/vzj2016.09.0090.

Benard, P., Zarebanadkouki, M., Hedwig, C., Holz, M., Ahmed, M.A. \& Carminati, A. 2018. Porescale distribution of mucilage a $\square$ ecting water repellency in the Rhizosphere. Vadose Zone Journal, 17, DOI: 10.2136/vzj2017.01.0013

Bengough, A. G. \& Mullins, C. E. 1991. Penetrometer resistance, root penetration resistance and root elongation rate in two sandy loam soils. Plant and Soil, 131, 59-66

Bengough, A. G., Mullins, C. E. \& Wilson, G. 1997. Estimating soil frictional resistance to metal probes and its relevance to the penetration of soil by roots. European Journal of Soil Science, 48, 603-612

Brax, M., Buchmann, C. \& Schaumann, G.E., 2017. Biohydrogel induced soil-water interactions: How to untangle the gel effect? A review. Journal of Plant Nutrition and Soil Science, 180, $121-141$.

Buchmann, C. \& Schaumann, G.E., 2017. Effect of water entrapment by a hydrogel on the microstructural stability of artificial soils with various clay content. Plant and Soil, 414, 181-198.

Carminati, A. 2013. Rhizosphere wettability decreases with root age: A problem or a strategy to increase water uptake of young roots? Frontiers in Plant Science, 4, 298.

Carminati, A., Zarebanadkouki, M., Kroener, E., Ahmed, M.A. \& Holz, M., 2016. Biophysical rhizosphere processes affecting root water uptake. Annals of Botany, 118, 561-571.

Chartier, M., Rostagno, C. \& Videla, L., 2013. Selective erosion of clay, organic carbon and total nitrogen in grazed semiarid rangelands of northeastern Patagonia, Argentina. Journal of Arid Environments, 88, 43-49 
Chenu, C. \& Guerif, J., 1991. Mechanical strength of clay-minerals as influenced by an adsorbed polysaccharide. Soil Science Society of America Journal, 55, 1076-1080.

Cole, D.M., Ringelberg, D.B. \& Reynolds, C.M., 2012. Small-Scale Mechanical Properties of Biopolymers. Journal of Geotechnical and Geoenvironmental Engineering, 138, 1063-1074.

Czarnes, S., Hallett, P. D., Bengough, G.B. \& Young, I.M. 2000. Root- and microbial-derived mucilages affect soil structure and water transport. European Journal of Soil Science, 51, $435-443$

Deng, J.Z., Orner, E.P., Chau, J.F., Anderson, E.M., Kadilak, A.L., Rubinstein, R.L., Bouchillon, G.M., Goodwin, R.A., Gage, D.J. \& Shor, L.M., 2015. Synergistic effects of soil microstructure and bacterial EPS on drying rate in emulated soil micromodels. Soil Biology \& Biochemistry, 83, 116-124.

Deng, W., Jeng D. S., Toorop, P.E., Squire, G.R. \& Iannetta, P.P.M. 2012. A mathematical model of mucilage expansion in myxospermous seeds of Capsella bursa-pastoris (shepherd's purse). Annals of Botany, 109, 419-427

Dexter, A. R. \& Watts, C.W., 2001. Tensile strength and friability. In: Soil and Environmental Analysis. Physical Methods (Eds K.A. Smith, C.E. Mullins). Dekker Press, New York, USA

Engelbrecht, M., Bochet, E. \& García-Fayos, P. 2014. Mucilage secretion: an adaptive mechanism to reduce seed removal by soil erosion? Biological Journal of the Linnean Society, 111, $241-251$

Gee, G.W. \& Bauder, J.W., 1986. Particle Size Analysis. In: Klute, A., Ed., Methods of Soils Analysis, American Society of Agronomy, Madison, 2, 47-56.

Ghani, A., Dexter, M., Perrott, K.W., 2003. Hot-water extractable carbon in soils: a sensitive measurement for determining impacts of fertilization, grazing and cultivation. Soil Biology \& Biochemistry. 35, 1231-1243. 
Glentworth, R., Romans, J.C.C., Laing, D., Shipley, B.M \& Birse, E.L. 2016. The Soils of the Country round Banchory, Stonehaven and Forfar (Sheets 66/67 - Banchory \& Stonehaven and 57 - Forfar). Ed. Bell, J.S. The James Hutton Institute

Hallett, P.D., Baumgart, T. \& Young, I. M. 2001. Subcritical water repellency of aggregates from a range of soil management practices. Soil Science Social of America journal, 65, 184-190

Hallett, P.D., Dexter, A.R. \& Seville, J.P.K. 1995. The application of fracture mechanics to crack propagation in dry soil. European Journal of Soil Science, 46, 591-599.

Hallett, P.D., Young, I.M., 1999. Changes to water repellence of soil aggregates caused by substrateinduced microbial activity. European Journal of Soil Science, 50, 35-40

Henao, L.J. \& Mazeau, K. 2009. Molecular modelling studies of clay-exopolysaccharide complexes: Soil aggregation and water retention phenomena. Materials Science \& Engineering CMaterials for Biological Applications, 29, 2326-2332.

Huang, J. Q., Li, Z. W., Nie, X. D., Zhang, J. C., Tang, Z. H., Ma, W. M., Yu, W. \& Zeng, G. M. 2014. Microbial responses to soil rewetting in erosional and depositional environments in relation to the organic carbon dynamics. Geomorphology, 204, 256-264.

Kay, B. D., 1990. Rates of change of soil structure under different cropping systems. Advances in Soil Science, 12, 1-52

Le Bissonnais, Y. 1996. Aggregate stability and assessment of soil crustability and erodibility: I. Theory and methodology. European Journal of Soil Science, 47, 425-437

Lin, K.Y., Daniel, J.R. \& Whistler, R.L. 1994. Structure of chia seed polysaccharide exudate. Carbohydrate. Polymers. 23, 13-18

Morel, J. L., Habib, L., Plantureux, S. \& Guckert, A., 1991. Influence of maize root mucilage on soil aggregate stability. Plant and Soil,136, 111-119

Naveed, M., Ahmed, M. A., Benard, P., Brown, L. K., George, T. S., Bengough, A. G., Roose, T., Koebernick, N., \& Hallett, P. D., 2019. Surface tension, rheology and hydrophobicity of 
rhizodeposits and seed mucilage influence soil water retention and hysteresis. Plant and Soil, DOI: 10.1007/s11104-019-03939-9

Naveed, M., Brown, L. K., Raffan, A. C., George, T. S., Bengough, A. G., Roose, T. , Sinclair, I., Koebernick, N., Cooper, L., Hackett, C. A. \& Hallett, P. D., 2017. Plant exudates may stabilize or weaken soil depending on species, origin and time. European Journal of Soil Science, 68, 806-816. doi: 10.1111/ejss.12487

Naveed, M., Brown, L.K., Raffan, A.C., George, T.S., Bengough, A.G., Roose, T., Sinclair, I., Koebernick, N., Cooper, L. \& Hallett, P.D., 2018. Rhizosphere-scale Quantification of Hydraulic and Mechanical Properties of Soil Impacted by Root and Seed Exudates. Vadose Zone Journal, 17, 12. DOI: 10.2136/vzj2017.04.0083

Oleghe, E., Naveed, M., Baggs, E.M. \& Hallett, P.D., 2017. Plant exudates improve the mechanical conditions for root penetration through compacted soils. Plant and Soil, 421, 19-30.

Papiernik, S., Lindstrom, M., Schumacher, J., Farenhorst, A., Stephens, K., Schumacher, T. \& Lobb, D. 2005. Variation in soil properties and crop yield across an eroded prairie landscape. Australia Journal of Soil and Water Conservation, 60, 388-395.

Peng, X. H., Hallett, P. D., Zhang, B. \& Horn, R. 2011. Physical response of rigid and non-rigid soils to analogues of biological exudates. European Journal of Soil Science, 62, 676-684

Shi, Z. H., Yue, B. J., Wang, L., Fang, N. F., Wang, D. \& Wu, F. Z., 2013. Effects of mulch cover rate on interrill erosion processes and the size selectivity of eroded sediment on steep slope. Soil Science Society of America Journal. 77, 257-267

Sinnett D., Morgan G., Williams M., Hctchings, T., 2008. Soil penetration resistance and tree root development. Soil Use and Management, 24, 273-280

Traoré, O., Groleau-Renaud, V., Plantureux, S.,Tubeileh, A. \& Befu-Tremblay, V., 2000. Effect of root mucilage and modelled root exudates on soil structure. European Journal of Soil Science, 51, 575-581 
Wang, Z.H., Fang, H. \& Chen, M.H. 2017. Effects of root exudates of woody species on the soil anti-erodibility in the rhizosphere in a karst region, China. PeerJ, 5, 24.

Webster, R. 2007. Analysis of variance, inference, multiple comparisons and sampling effects in soil research. European Journal of Soil Science, 58, 74-82.

Zhang, B., Hallett, P. D. \& Zhang, G. 2008. Increase in the fracture toughness and bond energy of clay by a root exudate. European Journal of Soil Science, 59, 855-862.

Zhang, B., Peng, X. H., Zhao, Q. G. \& Hallett, P. D. 2004. Eluviation of dissolved organic carbon under wetting and drying and its influence on water infiltration in degraded soils restored with vegetation. European Journal of Soil Science, 55, 725-737 


\section{Tables}

Table 1. Selected soil properties from the midslope and footslope of the slope.

Table 2. The mass balance of dissolved organic carbon (mg) in different depths of soil cores (kg) with mucilage amendment and wetting and drying cycles.

Table 3. Soil penetration resistance (MPa) as affected by slope position, mucilage amendment and wetting and drying (WD) cycles at different water potentials.

Table 4. Sorptivity and Repellency of soil cores formed from soil as affected by slope position, mucilage amendment and wetting and drying (WD) cycles.

Table 5. Correlations between soil hydrological and mechanical properties and soil pore structure. 
Table 1. Selected soil properties from the midslope and footslope of the slope

\begin{tabular}{|c|c|c|c|c|c|c|c|c|}
\hline \multirow[b]{2}{*}{ Position } & \multicolumn{4}{|c|}{ Soil texture / \% } & \multirow[b]{2}{*}{$\begin{array}{c}\mathrm{TN} \\
/ \mathrm{g} \mathrm{kg}^{-1}\end{array}$} & \multirow[b]{2}{*}{$\begin{array}{l}\mathrm{SOC} \\
/ \mathrm{g} \mathrm{kg}^{-1}\end{array}$} & \multirow{2}{*}{$\begin{array}{c}\mathrm{pH} \\
\left(\mathrm{H}_{2} \mathrm{O}\right)\end{array}$} & \multirow[b]{2}{*}{$\begin{array}{c}\mathrm{EC} \\
/ \mu \mathrm{cm}^{-1}\end{array}$} \\
\hline & $\begin{array}{c}\text { Sand } \\
2-0.02 \mathrm{~mm}\end{array}$ & $\begin{array}{c}\text { Silt } \\
0.02- \\
0.002 \mathrm{~mm} \\
\end{array}$ & $\begin{array}{c}\text { Clay } \\
<0.002 \mathrm{~mm}\end{array}$ & $\begin{array}{c}\text { Particle } \\
\text { 2-0.2 mm }\end{array}$ & & & & \\
\hline Midslope & $78.0 \pm 0.4$ & $13.9 \pm 0.2$ & $8.2 \pm 0.4$ & $28.2 \pm 0.5$ & $1.85 \pm 0.11$ & $18.5 \pm 1.4$ & $5.8 \pm 0.0$ & $46.4 \pm 2.5$ \\
\hline Footslope & $64.6 \pm 0.4$ & $21.2 \pm 0.3$ & $14.2 \pm 0.4$ & $8.5 \pm 0.2$ & $1.57 \pm 0.02$ & $19.5 \pm 2.0$ & $6.4 \pm 0.0$ & $67.9 \pm 0.3$ \\
\hline
\end{tabular}

Data are mean \pm standard error of three replicates 
Table 2. The mass balance of dissolved organic carbon (mg) in different depths of soil cores (kg) with mucilage amendment and wetting and drying cycles.

\begin{tabular}{|c|c|c|c|c|c|c|c|c|}
\hline \multirow{2}{*}{$\begin{array}{l}\text { Slope } \\
\text { position }\end{array}$} & & \multirow[b]{2}{*}{ Pre WD } & \multicolumn{3}{|c|}{$0 \mathrm{WD}$} & \multicolumn{3}{|c|}{$5 \mathrm{WD}$} \\
\hline & & & water & $\begin{array}{c}0.46 \mathrm{~g} \mathrm{C} \mathrm{kg}^{-1} \\
\text { mucilage }\end{array}$ & $\begin{array}{l}2.3 \mathrm{~g} \mathrm{C} \mathrm{kg}^{-1} \\
\text { mucilage }\end{array}$ & water & $\begin{array}{c}0.46 \mathrm{~g} \mathrm{C} \mathrm{kg}^{-1} \\
\text { mucilage }\end{array}$ & $\begin{array}{c}2.3 \mathrm{~g} \mathrm{C} \mathrm{kg}^{-1} \\
\text { mucilage }\end{array}$ \\
\hline \multirow{6}{*}{$\begin{array}{l}\text { Mid } \\
\text { slope }\end{array}$} & Top & 24 & $39(+15)$ & $38(+14)$ & $53(+29)$ & $99(+75)$ & $101(+77)$ & $168(+138)$ \\
\hline & Interior & 100 & $87(-13)$ & $96(-4)$ & $120(+20)$ & $96(-4)$ & $103(+3)$ & $109(+9)$ \\
\hline & Bottom & 23 & $21(-2)$ & $21(-2)$ & $29(+6)$ & $20(-3)$ & $20(-3)$ & $24(+1)$ \\
\hline & Whole & 147 & 147 & $155(+8)$ & $203(+55)$ & $215(+68)$ & $224(+77)$ & $295(+148)$ \\
\hline & ${ }^{1} \mathrm{DOC} \mathrm{fr}$ & nucilage & 0 & -8 & -55 & 0 & -23 & -94 \\
\hline & DOC fro & $\mathrm{OC}$ & 0 & 0 & 0 & -68 & -54 & -54 \\
\hline \multirow{6}{*}{$\begin{array}{l}\text { Foot } \\
\text { slope }\end{array}$} & Tор & 22 & $33(+11)$ & $34(+12)$ & $45(+23)$ & $87(+65)$ & $88(+66)$ & $122(+100)$ \\
\hline & Interior & 93 & $83(-10)$ & $94(+1)$ & $115(+22)$ & $95(+2)$ & $99(+6)$ & $115(+22)$ \\
\hline & Bottom & 22 & $20(-2)$ & $23(+1)$ & $28(+6)$ & $20(-2)$ & 22 & $25(+3)$ \\
\hline & Whole & 137 & 137 & $151(+14)$ & $188(51)$ & $202(+65)$ & $209(+72)$ & $262(+125)$ \\
\hline & DOC fro & ucilage & 0 & -14 & -51 & 0 & -23 & -94 \\
\hline & DOC fro & OC & 0 & 0 & 0 & -65 & -49 & -31 \\
\hline
\end{tabular}

Note: The variation of DOC in different soil layer or whole soil core were listed in the bracket. “+” means that DOC is in the inflow state; "-" means that DOC is in the outflow state or decomposed from mucilage or soil organic carbon (SOC)

1. The increased mass of DOC in the whole soil core derived from amended mucilage or SOC, and we assumed that the mucilage was preferentially decomposed into DOC than SOC; The additive maximum OC mass from $0.46 \mathrm{~g} \mathrm{C}$ $\mathrm{kg}^{-1}$ mucilage and $2.3 \mathrm{~g} \mathrm{C} \mathrm{kg}^{-1}$ mucilage for $1 \mathrm{~kg}$ soil were $23 \mathrm{mg}$ and $94 \mathrm{mg}$, respectively. 
Table 3. Soil penetration resistance (MPa) as affected by slope position, mucilage amendment and wetting and drying (WD) cycles at different water potentials.

\begin{tabular}{|c|c|c|c|c|c|c|c|}
\hline \multirow{2}{*}{$\begin{array}{c}\text { Water } \\
\text { Potential }\end{array}$} & \multirow[b]{2}{*}{ Cycles } & \multicolumn{3}{|c|}{ Midslope } & \multicolumn{3}{|c|}{ Footslope } \\
\hline & & water & $\begin{array}{c}0.46 \mathrm{~g} \mathrm{C} \mathrm{kg}^{-1} \\
\text { mucilage }\end{array}$ & $\begin{array}{c}2.3 \mathrm{~g} \mathrm{C} \mathrm{kg}^{-1} \\
\text { mucilage }\end{array}$ & water & $\begin{array}{c}0.46 \mathrm{~g} \mathrm{C} \mathrm{kg}^{-1} \\
\text { mucilage }\end{array}$ & $\begin{array}{l}2.3 \mathrm{~g} \mathrm{C} \mathrm{kg}^{-1} \\
\text { mucilage }\end{array}$ \\
\hline \multirow{3}{*}{$-5 \mathrm{KPa}$} & $0 \mathrm{WD}$ & $0.648 \pm 0.018$ & $0.654 \pm 0.017$ & $0.786 \pm 0.015$ & $0.483 \pm 0.015$ & $0.429 \pm 0.016$ & $0.588 \pm 0.027$ \\
\hline & $1 \mathrm{WD}$ & $0.707 \pm 0.021$ & $0.600 \pm 0.013$ & $0.724 \pm 0.020$ & $0.425 \pm 0.015$ & $0.494 \pm 0.016$ & $0.530 \pm 0.014$ \\
\hline & $5 \mathrm{WD}$ & $0.480 \pm 0.035$ & $0.516 \pm 0.034$ & $0.744 \pm 0.048$ & $0.355 \pm 0.024$ & $0.426 \pm 0.014$ & $0.493 \pm 0.012$ \\
\hline \multirow{3}{*}{$-30 \mathrm{KPa}$} & $0 \mathrm{WD}$ & $2.160 \pm 0.100$ & $1.878 \pm 0.034$ & $2.086 \pm 0.108$ & $1.256 \pm 0.029$ & $1.274 \pm 0.049$ & $1.321 \pm 0.061$ \\
\hline & $1 \mathrm{WD}$ & $2.052 \pm 0.046$ & $2.113 \pm 0.055$ & $2.138 \pm 0.048$ & $1.305 \pm 0.035$ & $1.402 \pm 0.039$ & $1.309 \pm 0.047$ \\
\hline & $5 \mathrm{WD}$ & $1.974 \pm 0.068$ & $2.003 \pm 0.060$ & $2.420 \pm 0.183$ & $1.380 \pm 0.031$ & $1.360 \pm 0.107$ & $1.496 \pm 0.051$ \\
\hline
\end{tabular}


Table 4. Sorptivity and Repellency of soil cores formed from soil as affected by slope position, mucilage amendment and wetting and drying (WD) cycles.

\begin{tabular}{|c|c|c|c|c|c|c|c|c|}
\hline & & & \multicolumn{3}{|c|}{ Midslope } & \multicolumn{3}{|c|}{ Footslope } \\
\hline & & & er & $\begin{array}{c}0.46 \mathrm{~g} \mathrm{C} \mathrm{kg}^{-1} \\
\text { mucilage }\end{array}$ & $\begin{array}{l}2.3 \mathrm{~g} \mathrm{C} \mathrm{kg}^{-} \\
{ }^{1} \text { mucilage }\end{array}$ & rater & $\begin{array}{c}0.46 \mathrm{~g} \mathrm{C} \mathrm{kg}^{-1} \\
\text { mucilage }\end{array}$ & $\begin{array}{c}2.3 \mathrm{~g} \mathrm{C} \mathrm{kg}^{-1} \\
\text { mucilage }\end{array}$ \\
\hline \multirow{9}{*}{$\begin{array}{c}\text { Top } \\
\text { surface }\end{array}$} & \multirow{3}{*}{$\mathrm{S}_{\mathrm{W}}$} & $0 \mathrm{WD}$ & $0.173 \pm 0.003$ & $0.180 \pm 0.002$ & $0.141 \pm 0.004$ & $0.136 \pm 0.004$ & $0.140 \pm 0.002$ & $0.141 \pm 0.004$ \\
\hline & & $1 \mathrm{WD}$ & $0.163 \pm 0.002$ & $0.214 \pm 0.004$ & $0.138 \pm 0.001$ & $0.126 \pm 0.004$ & $0.135 \pm 0.002$ & $0.139 \pm 0.005$ \\
\hline & & $5 \mathrm{WD}$ & $0.289 \pm 0.006$ & $0.274 \pm 0.014$ & $0.122 \pm 0.008$ & $0.230 \pm 0.006$ & $0.216 \pm 0.029$ & $0.182 \pm 0.018$ \\
\hline & \multirow{3}{*}{$\mathrm{S}_{\mathrm{E}}$} & $0 \mathrm{WD}$ & $0.252 \pm 0.006$ & $0.248 \pm 0.005$ & $0.231 \pm 0.004$ & 0.171 & $0.174 \pm 0.002$ & $0.203 \pm 0.004$ \\
\hline & & $1 \mathrm{WD}$ & $0.241 \pm 0.002$ & $.261 \pm 0.004$ & $0.231 \pm 0.004$ & $0.162 \pm 0.003$ & $0.172 \pm 0.002$ & $0.196 \pm 0.004$ \\
\hline & & $5 \mathrm{WD}$ & $0.449 \pm 0.067$ & $0.430 \pm 0.025$ & $0.278 \pm 0.018$ & $0.317 \pm 0.038$ & $0.366 \pm 0.016$ & $0.340 \pm 0.050$ \\
\hline & \multirow{3}{*}{ WR } & $\mathrm{VD}$ & $2.763 \pm 0.052$ & $2.689 \pm 0.069$ & 3.21 & $2.455 \pm 0.074$ & 2.422 & $2.819 \pm 0.101$ \\
\hline & & $1 \mathrm{WD}$ & $2.887 \pm 0.051$ & $2.379 \pm 0.065$ & $3.252 \pm 0.051$ & $2.515 \pm 0.050$ & $2.494 \pm 0.051$ & $2.769 \pm 0.112$ \\
\hline & & $5 \mathrm{WD}$ & $2.634 \pm 0.266$ & $3.122 \pm 0.109$ & $4.500 \pm 0.202$ & $2.885 \pm 0.264$ & $3.301 \pm 0.353$ & $3.869 \pm 0.447$ \\
\hline \multirow{9}{*}{$\begin{array}{l}\text { Bottom } \\
\text { surface }\end{array}$} & \multirow{3}{*}{ Sw } & $0 \mathrm{WD}$ & $0.214 \pm 0.009$ & $0.186 \pm 0.003$ & $0.139 \pm 0.005$ & $0.134 \pm 0.002$ & $0.144 \pm 0.002$ & $0.128 \pm 0.003$ \\
\hline & & $1 \mathrm{WD}$ & $0.191 \pm 0.005$ & $0.203 \pm 0.006$ & $0.149 \pm 0.006$ & $0.140 \pm 0.002$ & $0.143 \pm 0.004$ & $0.136 \pm 0.005$ \\
\hline & & $5 \mathrm{WD}$ & $0.648 \pm 0.075$ & $0.422 \pm 0.040$ & $0.202 \pm 0.005$ & $0.801 \pm 0.046$ & $0.754 \pm 0.059$ & $0.467 \pm 0.047$ \\
\hline & \multirow{3}{*}{$\mathrm{S}_{\mathrm{E}}$} & $0 \mathrm{WD}$ & $0.252 \pm 0.003$ & $0.255 \pm 0.003$ & $0.243 \pm 0.004$ & $0.172 \pm 0.002$ & $0.183 \pm 0.002$ & $0.194 \pm 0.002$ \\
\hline & & $1 \mathrm{WD}$ & $0.249 \pm 0.006$ & $0.268 \pm 0.004$ & $0.235 \pm 0.004$ & $0.170 \pm 0.006$ & $0.184 \pm 0.003$ & $0.206 \pm 0.009$ \\
\hline & & $5 \mathrm{WD}$ & $0.867 \pm 0.094$ & $0.615 \pm 0.094$ & $0.334 \pm 0.003$ & $0.661 \pm 0.090$ & $0.623 \pm 0.081$ & $0.390 \pm 0.029$ \\
\hline & \multirow{3}{*}{ WR } & $0 \mathrm{WD}$ & $2.317 \pm 0.099$ & $2.664 \pm 0.065$ & $3.419 \pm 0.119$ & $2.497 \pm 0.036$ & $2.470 \pm 0.036$ & $2.959 \pm 0.074$ \\
\hline & & $1 \mathrm{WD}$ & $2.540 \pm 0.037$ & $2.590 \pm 0.082$ & $3.100 \pm 0.130$ & $2.365 \pm 0.079$ & $2.501 \pm 0.087$ & $2.957 \pm 0.085$ \\
\hline & & $5 \mathrm{WD}$ & $2.639 \pm 0.400$ & $2.671 \pm 0.309$ & $3.220 \pm 0.108$ & $1.420 \pm 0.256$ & $1.537 \pm 0.190$ & $1.650 \pm 0.196$ \\
\hline
\end{tabular}

Sw: water sorptivity $\left(\mathrm{mm} \mathrm{s}^{-1 / 2}\right)$; $\mathrm{S}_{\mathrm{E}}$ : ethanol sorptivity $\left(\mathrm{mm} \mathrm{s}^{-1 / 2}\right)$; WR: water repellency;

Data are mean \pm standard error 
Table 5. Correlations between soil hydrological and mechanical properties and soil pore structure.

\begin{tabular}{|c|c|c|c|c|c|c|c|c|}
\hline $\begin{array}{c}\text { Slope } \\
\text { Position }\end{array}$ & $\begin{array}{c}\text { Soil } \\
\text { porosity }\end{array}$ & $\begin{array}{l}\text { Water } \\
\text { Sorptivity }\end{array}$ & $\begin{array}{l}\text { Ethanol } \\
\text { Sorptivity }\end{array}$ & $\begin{array}{c}\text { Water } \\
\text { Repellency }\end{array}$ & $\begin{array}{l}\text { DOC in top } \\
\text { surface soil }\end{array}$ & $\begin{array}{l}\text { DOC in bottom } \\
\text { surface soil }\end{array}$ & $\begin{array}{c}\text { Aggregate } \\
\text { stability }\end{array}$ & $\begin{array}{l}\text { Tensile } \\
\text { strength }\end{array}$ \\
\hline \multirow[t]{4}{*}{ midslope } & macro- & $0.57^{* *}$ & $0.80^{* *}$ & $0.36^{*}$ & $0.67^{* *}$ & $-0.53^{*}$ & $-0.65^{* *}$ & $-0.87^{* *}$ \\
\hline & meso- & $0.86^{* *}$ & $0.93^{* *}$ & -0.04 & $0.44^{*}$ & $-0.73^{* *}$ & $-0.90^{* *}$ & $-0.94^{* *}$ \\
\hline & micro- & $-0.57^{* *}$ & $-0.73^{* *}$ & -0.24 & $-0.68^{* *}$ & $0.77^{* *}$ & $0.76^{* *}$ & $0.86^{* *}$ \\
\hline & Total & $0.70^{* *}$ & $0.88^{* *}$ & 0.18 & $0.53^{*}$ & $-0.53^{*}$ & $-0.72^{* *}$ & $-0.89^{*}$ \\
\hline \multirow[t]{4}{*}{ footslope } & macro- & $0.79^{* *}$ & $0.74^{* *}$ & 0.25 & $0.52^{*}$ & $-0.67^{* *}$ & $-0.90^{* *}$ & $-0.94^{* *}$ \\
\hline & meso- & $0.80^{* *}$ & $0.75^{* *}$ & 0.23 & $0.55^{*}$ & $-0.67^{* *}$ & $-0.92^{* *}$ & $-0.91^{* *}$ \\
\hline & micro- & $-0.45^{* *}$ & $-0.31^{*}$ & 0.11 & -0.29 & $0.88^{* *}$ & $0.80^{* *}$ & $0.49^{* *}$ \\
\hline & Total & $0.77^{* *}$ & $0.77^{* *}$ & $0.34^{*}$ & $0.59^{*}$ & $-0.51^{*}$ & $-0.79^{* *}$ & $-0.94^{* *}$ \\
\hline
\end{tabular}

*,** indicate the significance of $p<0.05$ and $p<0.01$, respectively. 


\section{Figures lists}

Fig.1. Dissolved organic carbon (DOC) concentration at different depths in the soil cores in the top soil layer ( $0-2 \mathrm{~mm}$ depth from the top surface), bottom soil layer (13-15 $\mathrm{mm}$ from the top surface), interior soil layer (2-13 $\mathrm{mm}$ from the top surface) and the whole soil core $(0-15 \mathrm{~mm})$ as affected by slope position, plant mucilage amendment and wetting/drying (WD) cycles.

Fig. 2. Percentage of water stable aggregates $(>0.25 \mathrm{~mm})$ of soil cores as affected by slope position, plant mucilage amendment and wetting/drying (WD) cycles. The dashed lines show the proportion of primary sand particles $>0.25 \mathrm{~mm}$, with $18.23 \%$ at the midslope and $6.12 \%$ in the footslope.

Fig.3 Tensile strength of soil cores as affected by slope position, plant mucilage amendment and wetting/drying (WD) cycles.

Fig.4 Soil porosity expressed as macroporosity $(>60 \mu \mathrm{m})$, mesoporosity $(10-60 \mu \mathrm{m})$ and microporosity $(<10 \mu \mathrm{m})$ of the soil cores as affected by slope position, plant mucilage amendment and wetting/drying (WD) cycles.

Fig. 5 Schematic model of soil physical stability as affected by slope position, plant mucilage amendment and wetting/drying (WD) cycles. 
Fig. 6 Relationship between water repellency and dissolved organic carbon (DOC) concentration in top surface soil layer $(0-2 \mathrm{~cm})$. The fitted line and analysis are for linear regression.

Fig. 7 Relationship between tensile strength and percentage of water stable aggregates (>0.25 mm) after wet sieving. The fitted line and analysis are for linear regression. 

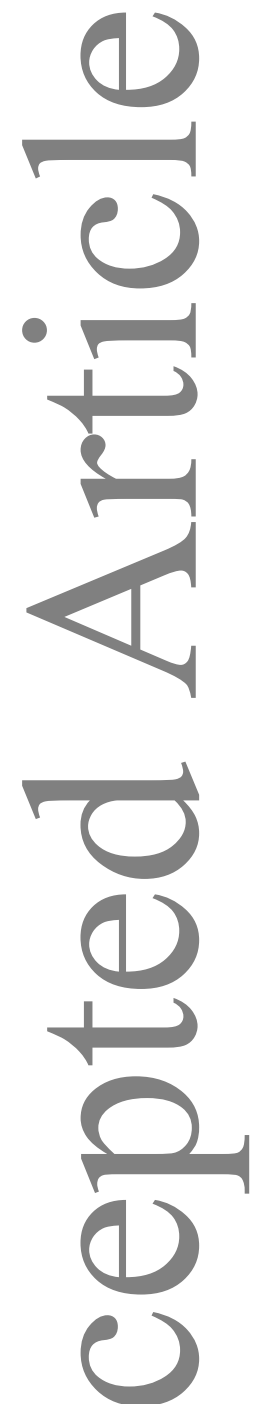

0
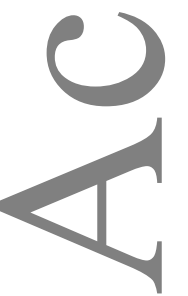

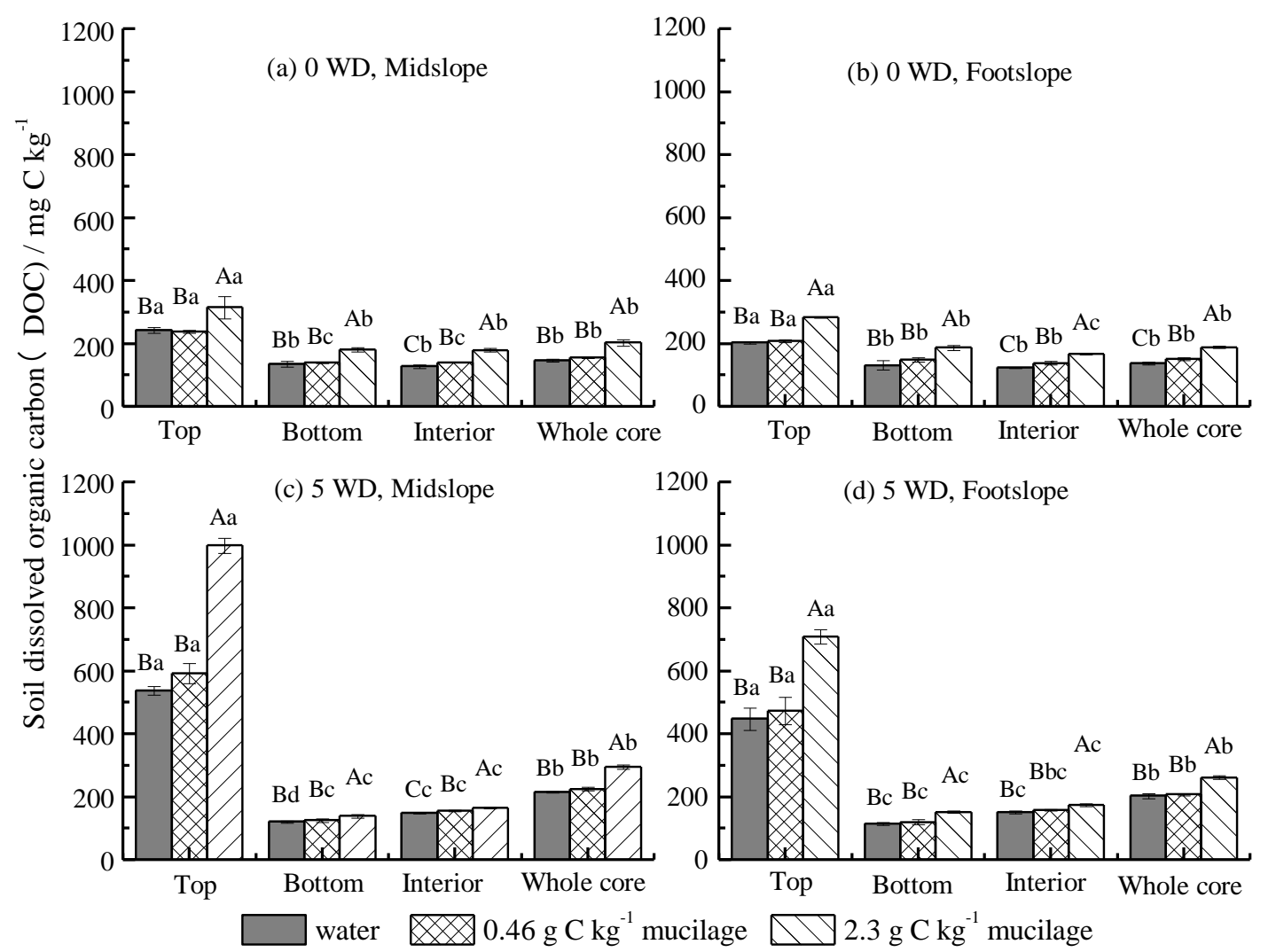

Fig.1. Dissolved organic carbon (DOC) concentration at different depths in the soil cores in the top soil layer ( $0-2 \mathrm{~mm}$ depth from the top surface), bottom soil layer (13-15 $\mathrm{mm}$ from the top surface), interior soil layer (2-13 $\mathrm{mm}$ from the top surface) and the whole soil core $(0-15 \mathrm{~mm})$ as affected by slope position, plant mucilage amendment and wetting/drying (WD) cycles

The uppercase letters mean the differences among mucilage treatments $(p<0.05)$, and the lowercase letters represent the differences among soil layers and whole soil core $(p<0.05)$. 


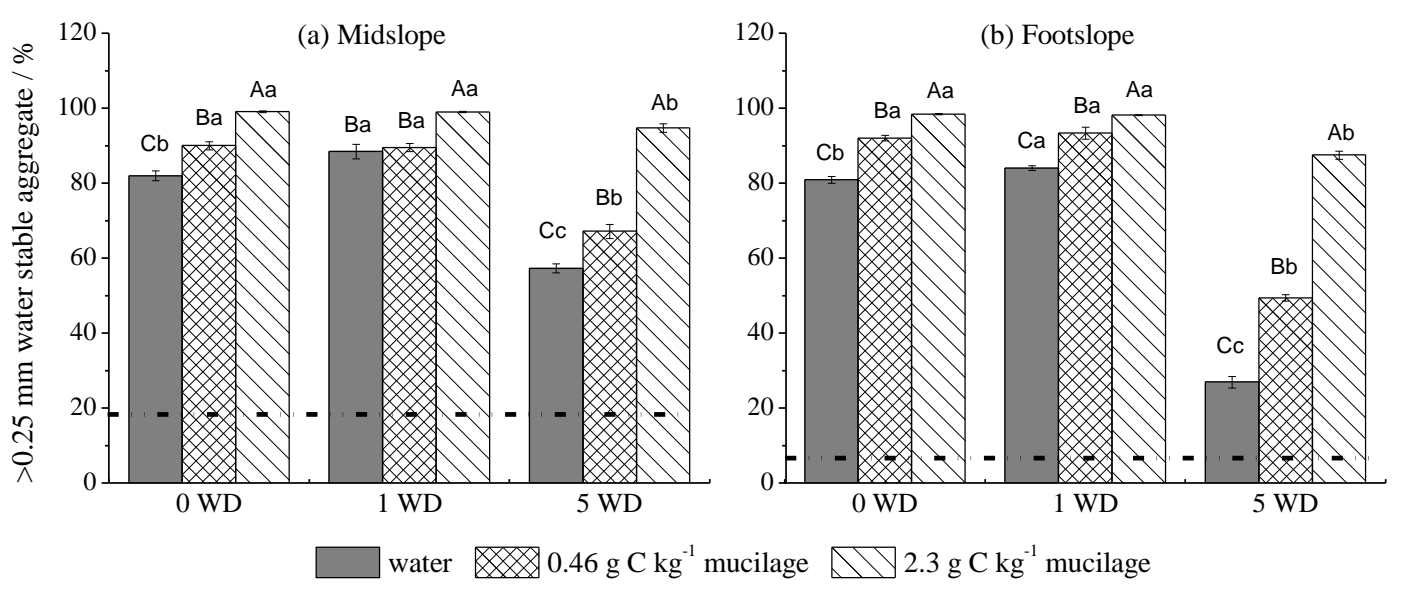

Fig. 2. Percentage of water stable aggregates $(>0.25 \mathrm{~mm})$ for soil cores as affected by slope position, plant mucilage amendment and wetting/drying (WD) cycles. The dashed lines show the proportion of primary sand particles $>0.25 \mathrm{~mm}$, with $18.23 \%$ at the midslope and $6.12 \%$ in the footslope

The uppercase letters mean the differences among mucilage treatments $(p<0.05)$, and the lowercase letters represent the differences among WD cycles $(p<0.05)$. 


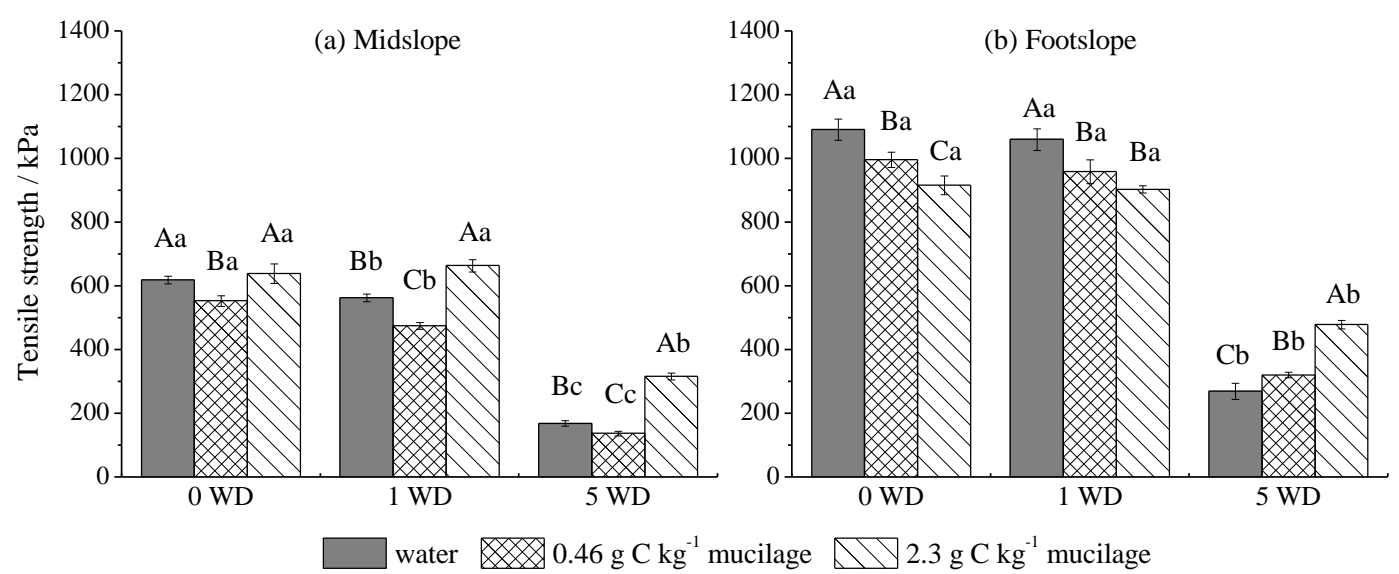

Fig.3 Tensile strength of soil cores as affected by slope position, plant mucilage amendment and wetting/drying (WD) cycles

The uppercase letters mean the differences among mucilage treatments $(p<0.05)$, and the lowercase letters represent the differences among WD cycles $(p<0.05)$. 


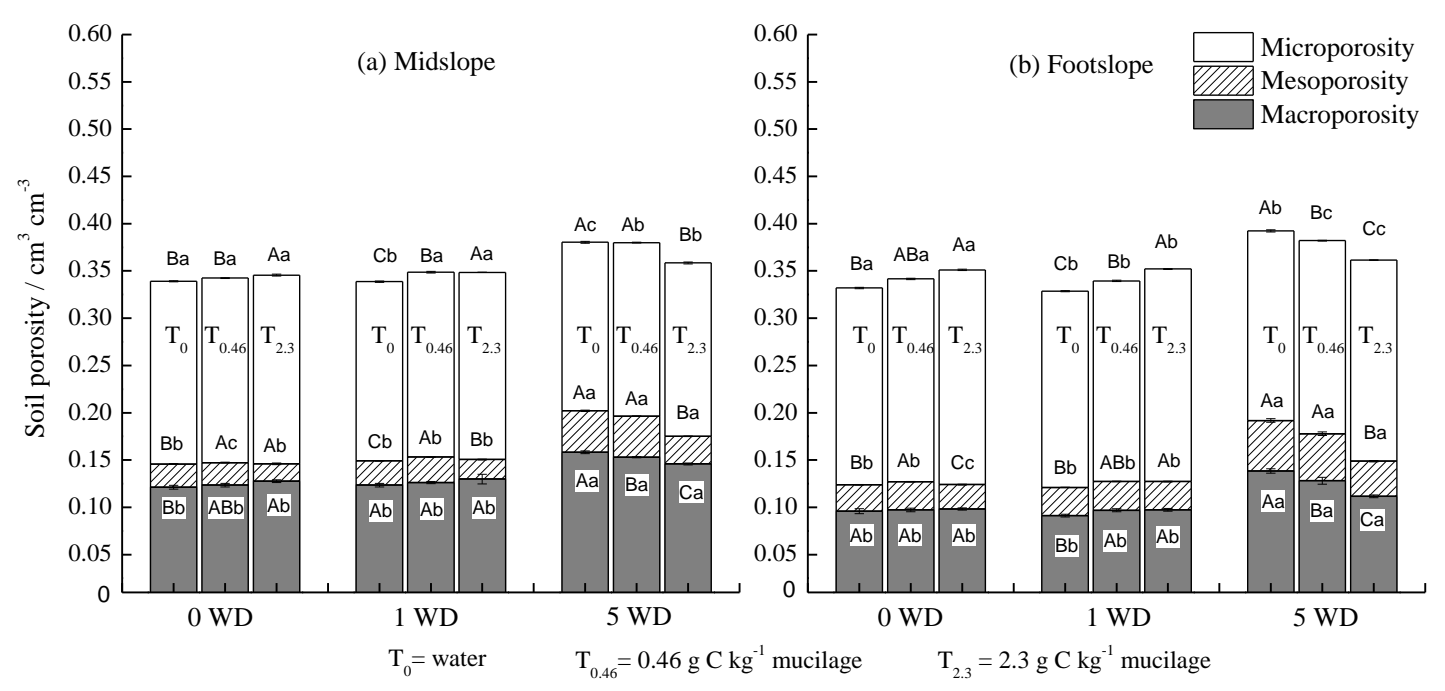

Fig.4 Soil porosity expressed as macroporosity $(>60 \mu \mathrm{m})$, mesoporosity $(10-60 \mu \mathrm{m})$ and microporosity $(<10 \mu \mathrm{m})$ of the soil cores as affected by slope position, plant mucilage amendment and wetting/drying (WD) cycles.

The uppercase letters mean the differences among mucilage treatments $(p<0.05)$, and the lowercase letters represent the differences among WD cycles $(p<0.05)$. 

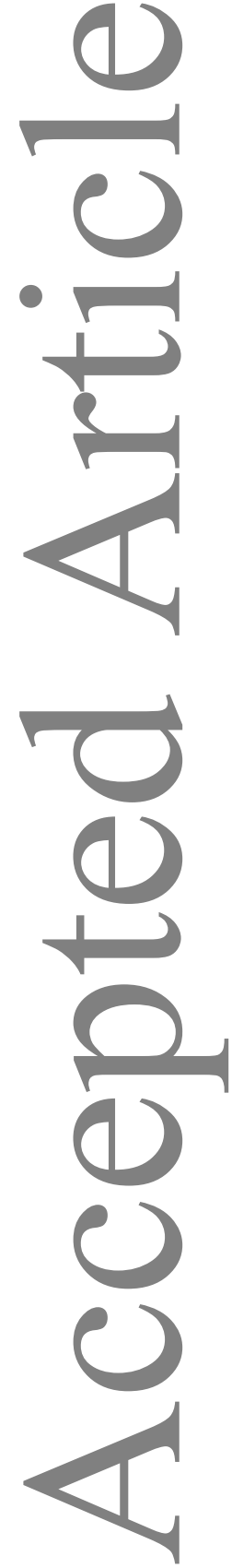

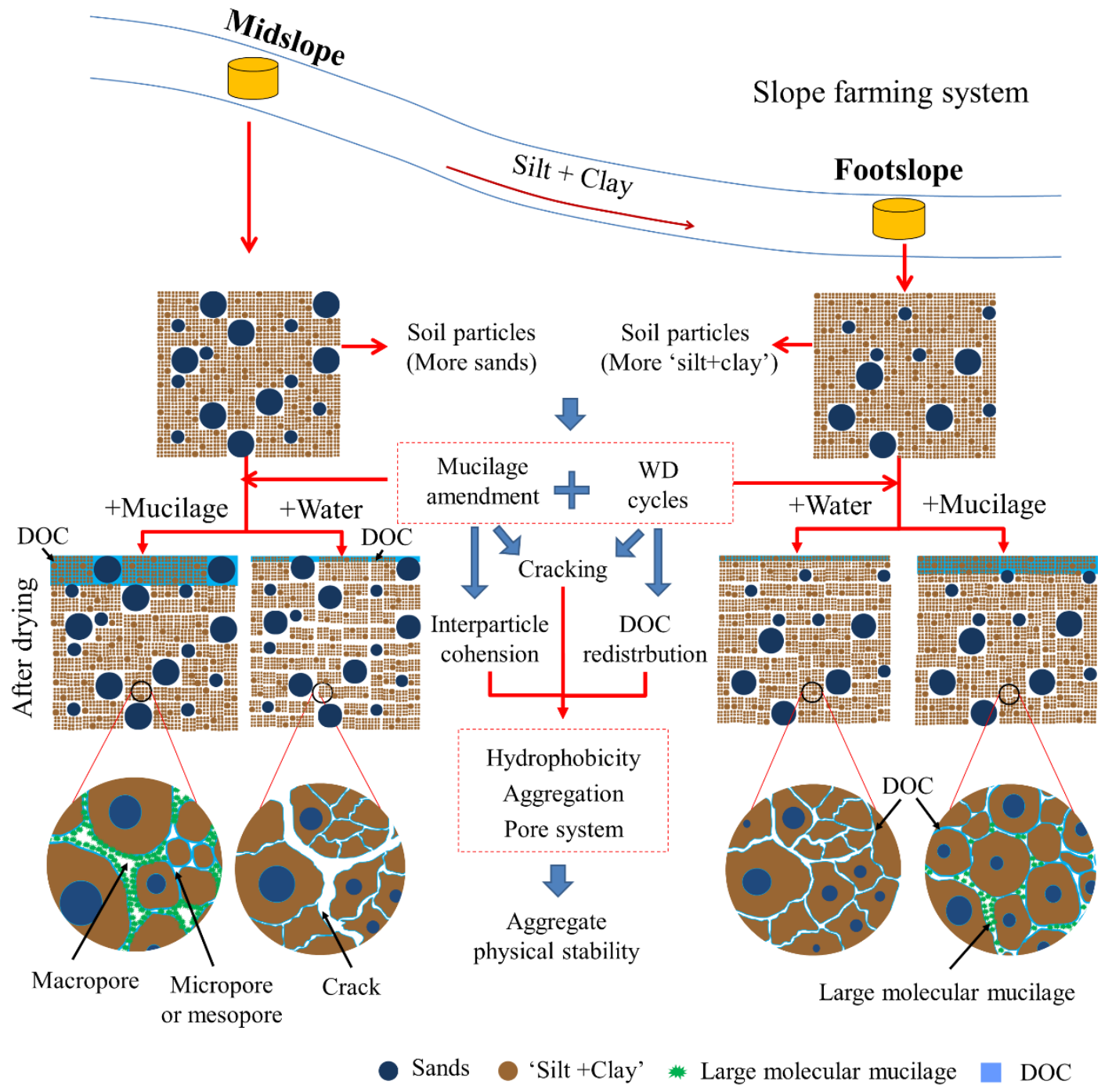

Fig. 5 Schematic model of soil physical stability as affected by slope position, plant mucilage amendment and wetting/drying (WD) cycles 


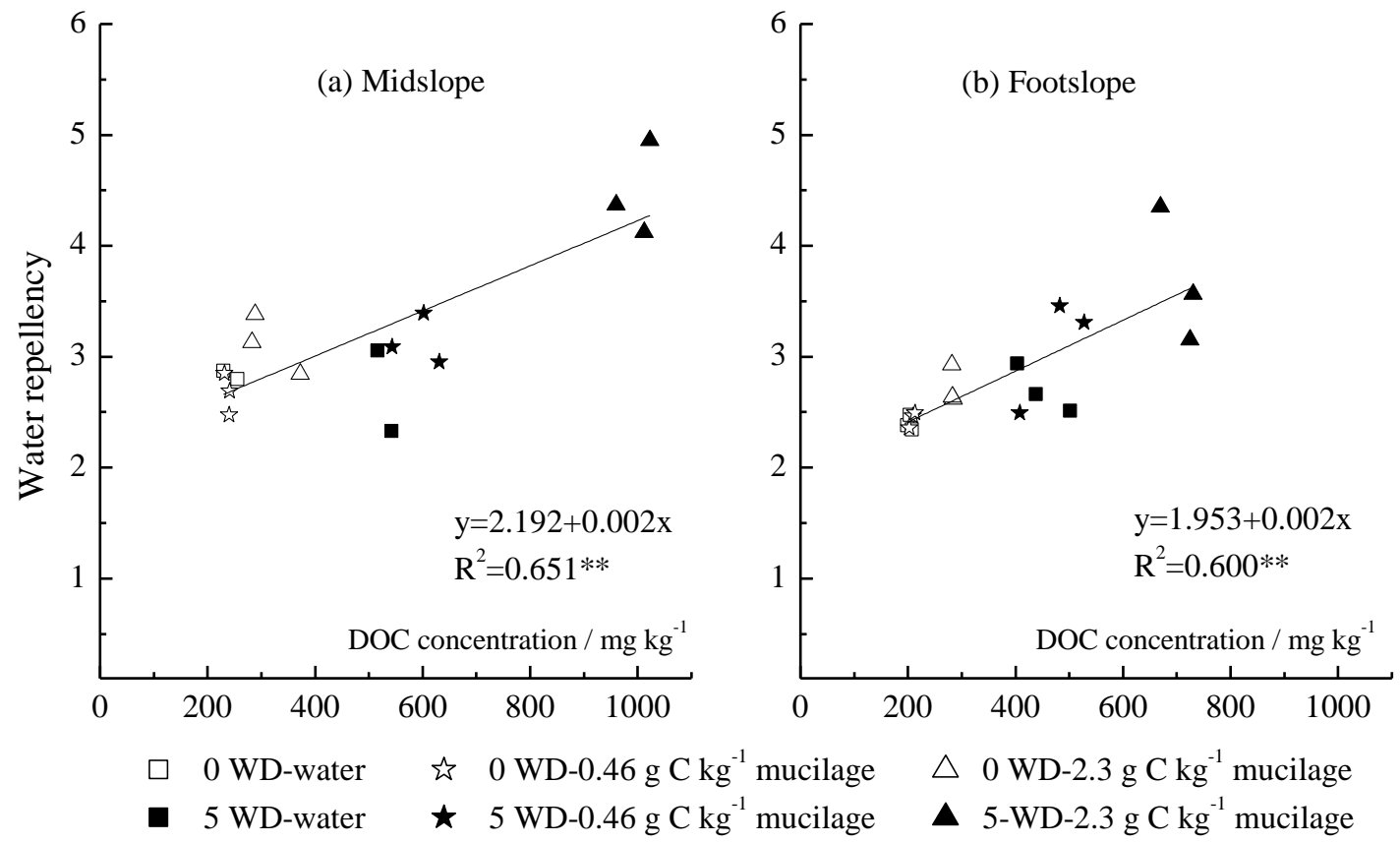

Fig. 6 Relationship between water repellency and dissolved organic carbon (DOC) concentration in top surface soil layer $(0-2 \mathrm{~cm})$. The fitted line and analysis are for linear regression 


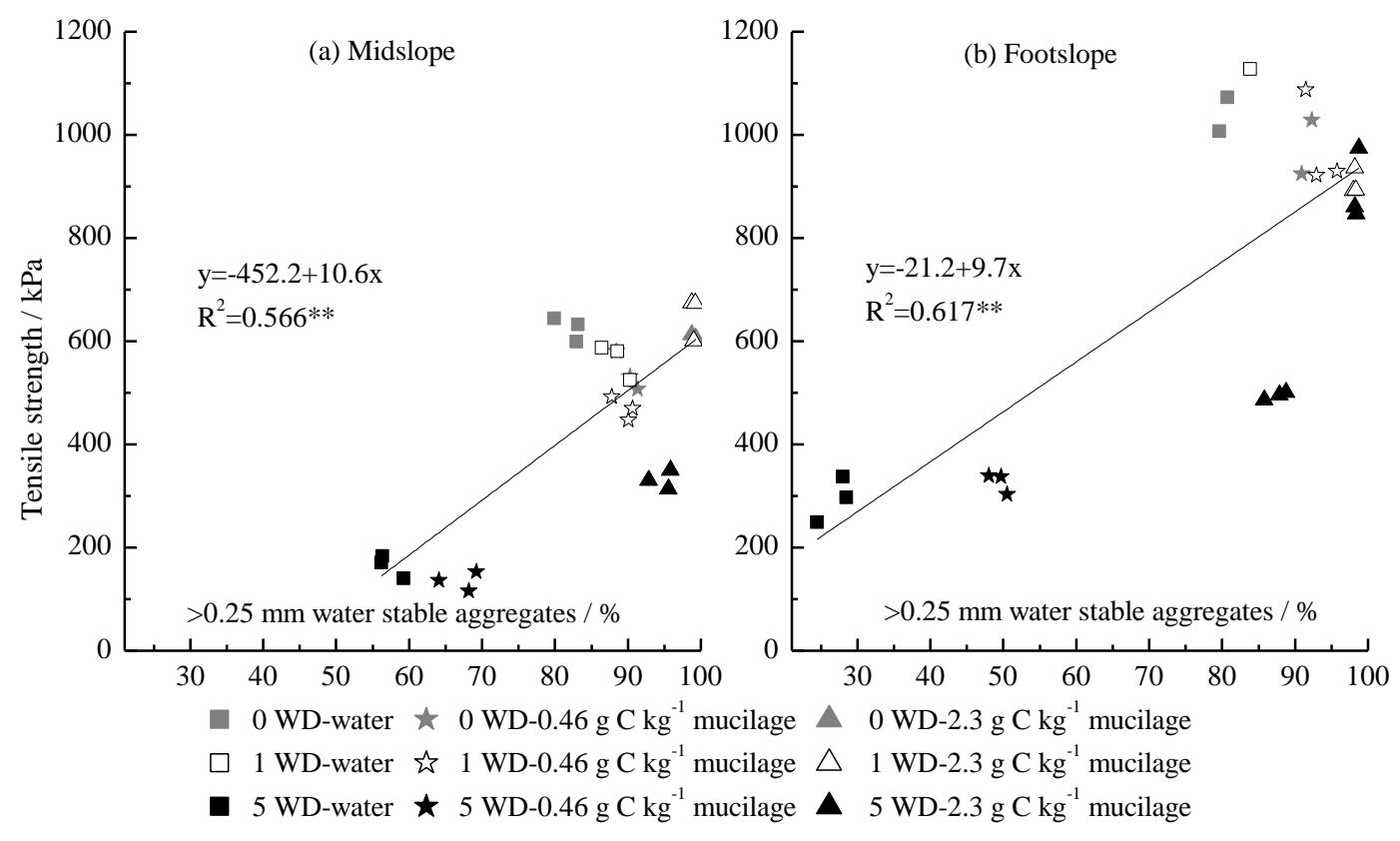

Fig. 7 Relationship between tensile strength and percentage of water stable aggregates $(>0.25 \mathrm{~mm})$ after wet sieving. The fitted line and analysis are for linear regression. 